\title{
УДК 378.013.77
}

DOI:10.31339/2617-9598-2018-2(2)-161-169

\author{
Юрков Олександр Сергійович \\ кандидат педагогічних наук, старший викладач кафедри психології \\ Мукачівський держсавний університет
}

\section{РОЗВИТОК ТВОРЧОГО ПОТЕНЦІАЛУ МАЙБУТНЬОГО ВЧИТЕЛЯ}

\begin{abstract}
Анотація. Стаття присвячена теоретичному аналізу та емпіричному дослідженні творчого потениіалу майбутнього вчителя за допомогою методик: Ваш творчий потениіал»(А.Н.Лук) та « Діагностика особистісних творчих здібностей» (Є.С.Тунік).За результатами дослідження зроблений висновок, щзо студентам притаманний середній творчий потенціал, вони є схильними до ризику та допитливості, мають середній рівень мотивації до успіху, і дані рекомендації студентам для розвитку творчого потенціалу.

Ключові слова: творчість, потениіал вчителя, творча діяльність, творча особистість, майстерність педагога.
\end{abstract}

Постановка проблеми. Актуальність проблеми розвитку творчої особистості педагога визначена завданнями національної педагогічної освіти, яка покликана формувати вчителя, здатного розвивати особистість дитини, зорієнтованого на особистісний та професійний саморозвиток і готового працювати творчо. Тому одним з головних завдань сучасного вищого навчального закладу є розвиток творчого потенціалу майбутніх педагогів, виховання їх як творчої, духовно збагаченої особистості.

Творчий потенціал вчителя розуміється дослідниками як невід’ємна складова частина сукупної культури фахівця, що вміщує наявні та потенційні здатності й можливості до створення чогось нового або перетворення пізнаного, як відкритість особистості до змін та самовдосконалення. Одночасно творчий потенціал вчителя виступає провідним чинником урізноманітнення та розвитку сукупної професійної культури педагога.

Тому, можна вважати, що й творчий потенціал вчителя як професіонала формується і розвивається в межах вищої освіти та збагачується в практичній діяльності. Проблема творчого потенціалу вчителя залишається актуальною та вимагає подальшого ії вивчення у процесі професійної підготовки майбутнього вчителя.

Аналіз останніх досліджень і публікацій. Творчий потенціал студентів майбутніх педагогів розглядається як обов'язкова внутрішня структура сучасного фахівця, що дозволяє не тільки домогтися компетентності та успішності в педагогічній діяльності, але й стати соціально значущою затребуваною особистістю. Специфіка педагогічної творчості вчителя розглянута в роботах В.І. Загвязинського, В.А. Кан-Калика, Н.В. Кичук, Л.М. Лузіної, М.Д. Нікандрова, М.М. Поташника та інших. [2, 3, 4, 5.]

У результаті аналізу наукових праць вище перелічених дослідників, виділяємо такі специфічні риси педагогічної творчості вчителя: 
• співтворчий характер щодо суб'єкта-об'єкта педагогічної діяльності;

• можливість суб'єктивної новизни й оригінальності процесу і результату;

• обмеженість творчої діяльності педагога часом;

• вплив на педагогічну творчість учителя багатьох факторів, які важко передбачити.[5].

Аналіз психолого-педагогічної літератури приводить до висновку, що рівень творчої діяльності педагога, визначається, як правило, залежно від того чи іншого конкретного напряму його педагогічної діяльності. Розвиток творчих здібностей майбутнього вчителя у процесі навчання у вузі є важливою умовою формування творчої особистості .

Центральною ланкою розвиваючого навчання $є$ створення оптимальних умов для розвитку загальних навчальних здібностей учнів і їхнього творчого потенціалу. У зв'язку з цим перед кожним вчителем стоїть завдання виявити, закріпити у школярів прагнення і потяг до творчого самовираження, а також створити всі необхідні умови для їхнього подальшого розвитку.

Виховання творчої особистості учня неможливе без права вчителя на власну творчість, на пошуки своєї технології, методів вирішення, яка відповідає його особистісним якостям. Творчий потенціал має дві сторони: творчість самого організатора навчально-виховного процесу вчителя і творчість учнів як необхідна умова удосконалення вчителя і розвитку творчих можливостей дітей. Педагог як суб'єкт педагогічної творчості повинен бути сформований як творча особистість.

На основі аналізу досліджень Ю.П. Азарова, Ю.К. Бабанського, О.О. Бодальова, В.І. Загвязінського, В.О. Кан-Калика, Н.В. Кичук, Н.В. Кузьміної, Л.М. Лузіної, М.Д. Нікандрова, М.М. Поташника, В.О. Сластьоніна, Р.Х. Шакурова та ін. можна сформулювати найважливіші якості вчителя, що сприяють успішній творчій діяльності:

- здатність до нестандартного рішення;

- пошуково-проблемний стиль мислення;

- уміння створювати проблемні, нестандартні навчальні і виховні ситуації;

- оригінальність у всіх сферах своєї діяльності;

- творча фантазія, розвинена уява;

- специфічні особистісні якості (сміливість, готовність до ризику, винахідливість, цілеспрямованість, оптимізм, ентузіазм, настирливість, упевненість, інтуїтивне відчуття нового та оригінального та ін..). [4,5.]

Творчий потенціал вчителя розуміється вченими як невід’ємна складова частина сукупної культури фахівця, що вміщує наявні та потенційні здатності й можливості до створення чогось нового або перетворення пізнаного, як відкритість особистості до змін та 
самовдосконалення. Одночасно творчий потенціал вчителя виступає провідним чинником урізноманітнення та розвитку сукупної професійної культури педагога. Тому, можна вважати, що й творчий потенціал вчителя як професіонала формується і розвивається в межах вищої освіти та збагачується в практичній діяльності. Проблема творчого потенціалу вчителя залишається актуальною та вимагає подальшого ії вивчення у процесі професійної підготовки майбутнього вчителя.

На сучасному етапі в навчальних закладах створюються сприятливі умови для розвитку педагогічної творчості вчителів і підвищення на цій основі результативності навчальновиховного процесу. Усе це ставить принципово нові вимоги перед керівниками щодо розвитку творчого потенціалу педагогічних колективів взагалі і кожного вчителя зокрема.

На теперішній час існує два наукових підходи до керівництва творчими процесами: оволодіння алгоритмами творчого процесу й побудова відповідних моделей різноманітних творчих рішень і створення найсприятливіших умов для творчої діяльності педагогів. У практиці керівництва загальноосвітньою школою і школою нового типу ці два процеси йдуть поруч у діалектичній єдності і взаємодії. [1,5.]

Творчий потенціал майбутнього педагога $\epsilon$ умовою формування педагогічної майстерності. Педагогічну майстерність можна розглядати як певний вияв викладачем свого «Я» в педагогічній діяльності. Безперечно, наслідки діяльності будь-якого майстра відбиваються в іiі результатах. Отже, суттєвим і головним показником його майстерності $€$ всебічний розвиток його вихованців.

Основними критеріями майстерності педагога виступають такі ознаки його діяльності:

- доцільність (за спрямованістю);

- ефективність (за результатами);

- гуманність, демократичність і діалогічність (за характером спілкування);

- оптимальність (у виборі змісту і засобів);

- творчість чи оригінальність (за змістом діяльності);

- науковість (за змістом матеріалу, що викладається, і за характером діяльності). [2]

Творчий потенціал будь-якої людини, зокрема і вчителя, характеризується низкою особливостей особистості, які називають ознаками творчої людини. При цьому автори пропонують різні групи таких ознак. Узагальнивши зазначені ознаки, класифікуємо їх таким чином:

- здатність особистості визначати і формулювати суперечності, ставити під сумнів те, що на перший погляд здається очевидним, уникати поверхневих формулювань;

- уміння усвідомити проблему і в той же час абстрагуватись від реальності, побачити перспективу; 
- здатність відмовитись від наслідування авторитетів;

- уміння побачити відомий об'єкт у новому контексті;

- готовність відмовитися від алгоритмічності та альтернативності суджень, відійти від звичної життєвої рівноваги й стійкості задля невизначеності та пошуку $[3,5$.

Аналіз вітчизняної та зарубіжної психолого-педагогічної літератури, стан вирішення цієї проблеми в практиці роботи загальноосвітніх шкіл, ліцеїв, гімназій, дозволили визначити такі основні педагогічні умови, які сприяють творчій діяльності, самореалізації особистості вчителя:

• забезпечення можливості реалізації вчителем своїх здібностей у найважливішій сфері його життєдіяльності - трудовій, а саме: у навчально-виховному процесі, у пізнавальній роботі з учнями, у системі підвищення кваліфікації з метою самоутвердження вчителя, розвитку в нього почуття самоповаги;

•детальне вивчення найбільш значущих для вчителів видів громадської діяльності і сприяння вияву особистості кожного вчителя у певному виді громадської діяльності для його самовизначення, самоутвердження й самореалізації через них;

•створення творчої атмосфери, здорового морально-психологічного клімату в колективі;

•утвердження в колективі демократичного стилю спілкування, свободи критики, творчих дискусій;

• забезпечення вільного часу вчителя (реалізація у практичній діяльності ідей інтенсифікації праці, оптимізації навчально-виховного процесу, наукової організації праці) 3 метою створення умов для самореалізації особистості вчителя на дозвіллі, підвищення його загальної культури;

• своєчасна позитивна оцінка діяльності вчителя для розвитку в нього почуття задоволення;

• уміння керівника помічати, розвивати й цінувати неповторну творчу індивідуальність кожного вчителя.[2,3.]

Формування творчого потенціалу фахівця залежить від систематичної послідовної участі студентів у нестандартній діяльності, накопичення досвіду творчої роботи, формування творчих умінь та навичок (бачення нових функцій відомого об'єкта, застосування ефективних способів діяльності в новій ситуації, комбінування відомих способів діяльності в нові, пошук альтернативних способів діяльності, визначення принципово нових підходів до розв'язання завдання.) Тому оволодіння практичними вміннями, що розглядаються як характеристики 
творчого потенціалу особистості майбутнього фахівця, і формування готовності до творчої професійної діяльності є основою для якісної освіти сучасного педагога.

Мета статті полягає у теоретичному аналізі, емпіричному дослідженні та виявленні рівня творчих здібностей майбутніх педагогів.

Результати дослідження. В дослідженні були використані методики для визначення творчого потенціалу майбутніх педагогів - «Ваш творчий потенціал» (А.Н.Лук), «Діагностика особистісних творчих здібностей» (Є.С.Тунік). Методика «Ваш творчий потенціал» містить шкали на визначення значного, середнього та маловираженого творчого потенціалу.[1.]

Аналіз результатів дозволив визначити рівень творчого потенціалу студентів 2 та 4 курсів і межі їхньої допитливості. Для наочного представлення результатів рівня творчого потенціалу студентів було побудовано діаграму ( Рис. 1).

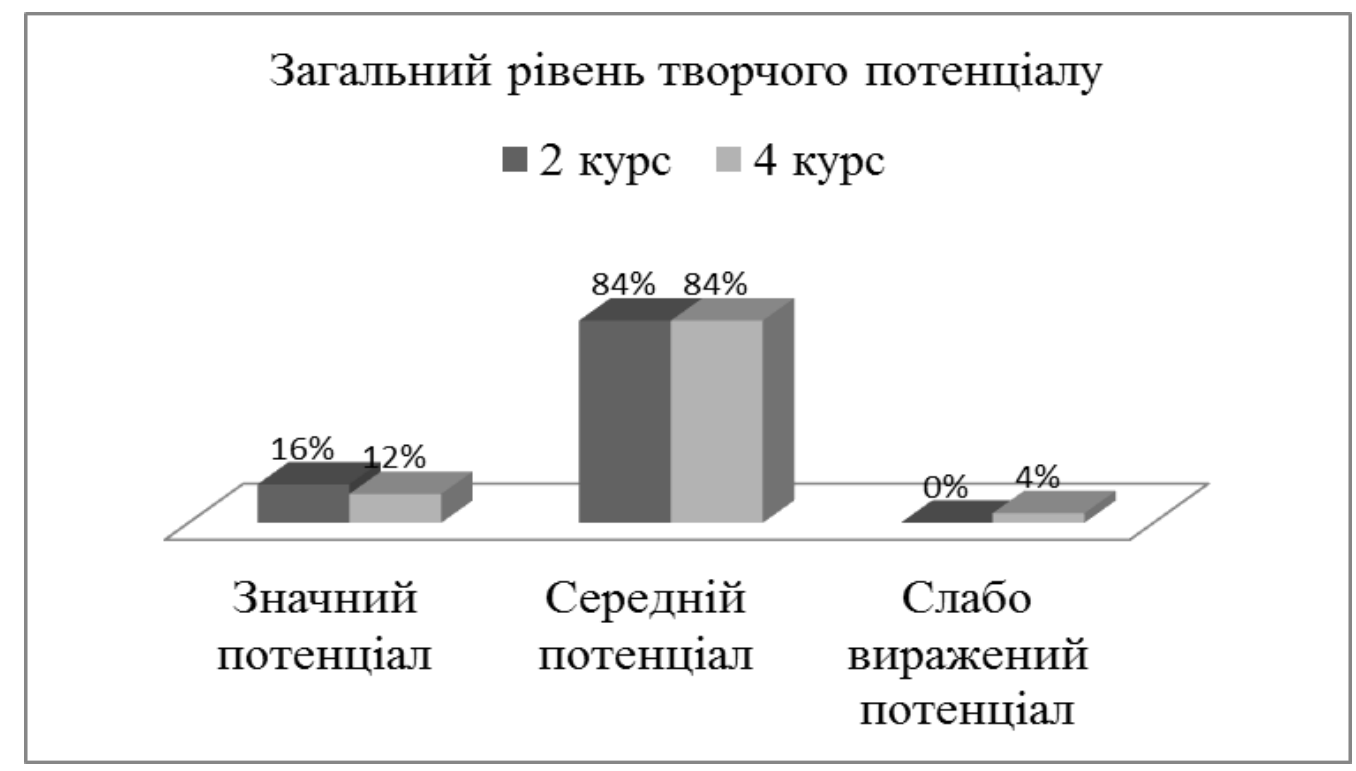

Рис.1.Показники рівня творчого потенціалу студентів (\%)

Середній потенціал є найбільш поширеним. Це свідчить про те, що 84\% студентів як 2 так і 4 курсів володіють частиною якостей, які дозволяють їм займатися творчістю, але заважають буденні проблеми. Однак не настільки, щоб вони не могли себе виявити як творчі особистості. Для них корисно знати, яких саме якостей їм бракує, щоб спробувати набути їх. А от слабо вираженого потенціалу зовсім немає у 2 курсу та лише є у двох людей (4\%) 4 курсу. Це нам говорить про те, що студенти таки оцінюють свої можливості, вірять у власні сили, усвідомлюють свої слабкості і долають їх.

Також є схожими показники і значного потенціалу. Він складає 16 \% у другого курсу та 12 \% у 4 курсу. Це не високий результат, але все таки є такі студенти, які шукають багатий вибір тем для творчості. Тому їм потрібно скористатися цими здібностями і втілити їх у справу, і їм стануть доступними усі види творчості. 
Ще однією 3 методик, які використовувалась у дослідженні $\epsilon$ «Діагностика особистісних творчих здібностей» (Є.С.Тунік). [1]

Під час оцінки даних опитувальника використовуються чотири фактори, що тісно корелюють із творчими проявами особистості. Вони включають: «Допитливість» (Д), «Уяву» (У), «Складність» (С) і «Схильність до ризику» (Р). Для наочного представлення рівнів творчих здібностей у групах було побудовано діаграму (Рис.2.).

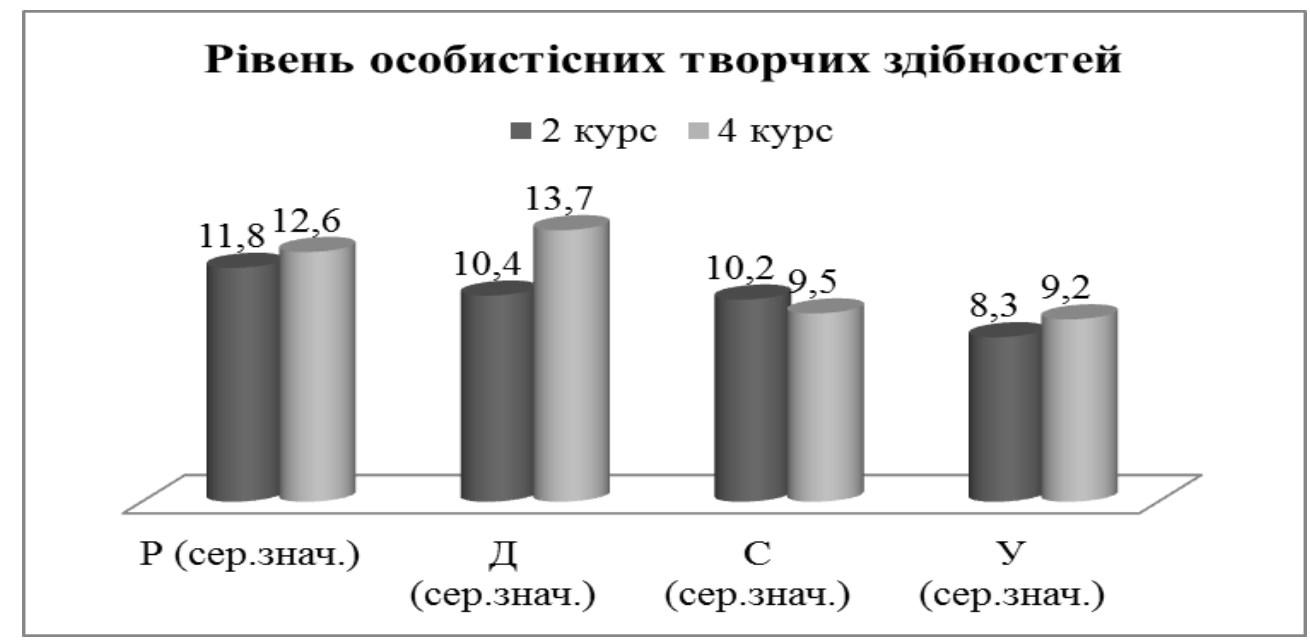

Рис. 2. Показники рівня особистісних творчих здібностей

Отже, за наведеними результатами можна зробити такі висновки: Студенти 2 курсу «Початкова освіта» отримали найбільший показник за шкалою «Схильність до ризику». Це свідчить про те, що такі студенти будуть відстоювати свої ідеї, не звертаючи уваги на реакцію інших; ставити перед собою високі цілі й будуть намагатися їх досягти; допускають для себе можливість помилок; люблять вивчати нові ідеї та не піддаються чужому впливу; у них не виникає занепокоєння, коли одногрупники, учителі або батьки виражають своє несхвалення; воліють мати шанс ризикнути, щоб довідатися, що із цього вийде.

А найнижчий показник отримано за шкалою «Уява». Це говорить про те, що в них не дуже виражена уява: не уявляють, як будуть вирішувати проблему; зовсім не дивуються із приводу різних ідей і подій.

При узагальненні результатів дослідження особистісних творчих здібностей студентів 4 курсу «Англійська філологія» найбільший показник отримано за шкалою «Допитливість». Це свідчить про те, що такі студенти із вираженою допитливістю найчастіше всіх цікавляться усім, їм подобається вивчати будову механізмів, вони постійно шукають нові шляхи (способи) мислення, люблять вивчати нові ідеї, шукають різні можливості рішення завдань, вивчають підручники, ігри, карти, картини й т.д., щоб пізнати якнайбільше .

Також у таблиці наведено загальний рівень особистісних творчих здібностей, їх сумарну оцінку у відсотках (\%), де можна побачити що студенти 2 курсу мають 40,9 \%, 4 курсу 
- 45\% творчих здібностей, які демонструють сильні сторони студентів. Але судячи 3 показників, які нижче середнього, їм потрібно займатись вдосконаленням допитливості, уяви та складності. Творчий розвиток майбутнього фахівця забезпечується засобами навчальновиховної діяльності.

Отже, за проведеними методиками у 2 курсу спеціальності «Початкова освіта» та 4 курсу «Англійська філологія» можна зробити наступні висновки: що у студентів спостерігається середній творчий потенціал а саме 84 \%, тобто вони все таки володіють частиною якостей, які дозволяють їм займатися творчістю і прагнути до покращення педагогічної майстерності. Також прослідковується, що серед другокурсників зовсім немає студентів які мають слабо виражений творчий потенціал., а в четвертокурсників це лише $4 \%$. Тому при порівнянні можна сказати, що все таки студенти обох груп усвідомлюють свої слабкості та з успіхом стараються їх долати для досягнення успіху.

За методикою «Діагностика особистісних творчих здібностей» (Є.Є. Тунік) можна прослідкувати те що, студенти обох курсів схильні до ризику та допитливості. Тобто студенти будуть відстоювати свої ідеї, не звертаючи уваги на реакцію інших; ставлять перед собою високі цілі й будуть намагатися їх здійснити; допускають для себе можливість помилок і провалів; люблять вивчати нові ідеї та не піддаються чужому впливу; у них не виникає занепокоєння, коли одногрупники, вчителі або батьки виражають своє несхвалення; воліють мати шанс ризикнути, щоб довідатися, що із цього вийде. Також прослідковуємо що студенти як 2 так і 4 курсу не є схильними до уяви. Тобто студенти не мають вираженої уяви: не уявляють, як будуть вирішувати проблему; зовсім не дивуються із приводу різних ідей i подій.

\section{Рекомендації студентам для розвитку творчого потенціалу $[2,3,4,5]$ :}

1. Потрібно сприймати наукову інформацію не для механічного запам'ятовування, а для логічного опрацювання, для встановлення причинно-наслідкових зв'язків. Важливо дотримуватися принципів наукової організації навчання, принципів наукової організації розумової праці.

2. Треба виявляти самостійність, критичність, уміння сприймати нові ідеї та відмовлятися від своїх помилкових думок. Багато важить набування пізнавальної компетентності, яка виявляється в таких уміннях :

- працювати $з$ текстом, який має недостатню або суперечливу інформацію (шукати необхідну інформацію);

- демонструвати вміння інтерпретувати суперечливий і неоднозначний матеріал;

- оцінювати суперечливу інформацію і формулювати гіпотези ії вирішення;

- у природничо-наукових знаннях робити пояснення, оцінювати альтернативні погляди, 
формувати своє ставлення до них.

Лише за таких умов розвивається творчий потенціал в професійної діяльності, а саме:

1. Продуктивність мислення, яка виявляється в кількісних характеристиках розгортання пізнавальної діяльності ( аналіз, синтез та ін.) і в якісних показниках ( успішне розв’язання навчальних завдань, формування власного погляду, свого ставлення до проблеми і свого бачення шляхів іiї вирішення).

2. Критичність мислення, прагнення до доказовості своїх ідей і міркувань.

3. Розвиток рефлективності: готовність до об'єктивної самооцінки; спроможність до дискусії з собою; здатність до саморегулювання.

4. Працелюбність, бути весь час у пошуках і русі, цілеспрямованість у праці.

5. Внутрішня єдність, цілісність і вибіркова позиція стосовно здійснення мети.

6. Загальний культурний рівень, розвиток духовно-моральних якостей особистості.

Висновки і перспективи подальших досліджень. Таким чином, з головних завдань сучасного вищого навчального закладу є розвиток творчого потенціалу майбутніх педагогів, виховання їх як творчої, духовно збагаченої особистості, що вміщує наявні та потенційні здатності й можливості до створення чогось нового або перетворення пізнаного, як відкритість особистості до змін та самовдосконалення. Результати дослідження показують, що середній творчий потенціал є найбільш поширеним. Але $є$ і позитивне формування значного рівня потенціалу, де студенти мають широкий вибір тем для творчості. Реалізація творчого потенціалу особистості постає ще більш гостро у студентському віці, коли сформованість вмінь і навичок спонукає до творчої діяльності. Творчість є необхідною складовою праці. Це підтверджує дослідження методики особистісних творчих здібностей, де виявлено рівень нижче середнього. Тому проблема розвитку творчого потенціалу майбутнього вчителя залишається актуальною та вимагає подальшого вивчення змісту, форм, методів, способів його формування у процесі професійної підготовки майбутнього учителя.

\section{СПИСОК ВИКОРИСТАНИХ ДЖЕРЕЛ}

1. Василькевич Я.М. Проблема діагностики творчих здібностей у діяльності психологічної служби ВНЗ / Я.М. Василькевич // Рідна школа . - 2008. —№10. - С. 43-45

2. Мартишина Н. В. Становление творческого потенциала личности педагога : моногр. / Н.В. Мартишина. - М. : Изд. дом Рос. акад. образования , 2006. - 264 с.

3. Подоляк Л.Г. Психологія вищої школи : Навчальний посібник. / Л.Г. Подоляк, В.І. Юрченко. - К. : ТОВ «Філ-студія», 2006. - 320 с.

4. Розвиток творчого потенціалу особистості [Електронний ресурс], 2010. - Режим доступу: http://www.confcontact.com/20102911/5_mursam.htm 
5. Риси педагогічної творчості вчителя [Електронний ресурс], 2014. - Режим доступу: https://videouroki.net/razrabotki/tvorcha-osobistist-u-pedagogitsi.html

\section{REFERENCES}

1. Vasylkevych YA.M., 2008. Problema diahnostyky tvorchykh zdibnostey u diyalnosti psykholohichnoyi sluzhby VNZ [Problem of diagnostics of creative abilities in the activity of psychological service of higher educational institutions], Ridna shkola \#10. - P. 43-45

2. Martyshyna N. V., 2006. Stanovlennya tvorchoho potentsialu osobystosti pedahoha: monohra. [Formation of the creative potential of the personality of the teacher], M.: Yzd. dom Ros. akad. osvity, $264 p$.

3. Podolyak L.H., 2006. Psykholohiya vyshchoyi shkoly: Navchalnyy posibnyk [Psychology of Higher Education], K.: TOV «Fil-studiya», 320p.

4. Rozvytok tvorchoho potentsialu osobystosti [Development of the creative potential of the individual], 2010. Retrieved from: http://www.confcontact.com/20102911/5_mursam.htm

5. Rysy pedahohichnoyi tvorchosti vchytelya [Types of Teacher's Pedagogical Creativity], 2014. Retrieved from: https://videouroki.net/razrabotki/tvorcha-osobistist-u-pedagogitsi.html.

Summary. The urgency of the problem of development of the teacher creative personality has been determined by the tasks of the national pedagogical education, which is designed to form a teacher capable of developing a child's personality, oriented to personal and professional self-development and ready to work creatively. Therefore, one of the main tasks of the modern higher educational institution is the development of creative potential of future teachers, education of them as a creative, spiritually enriched personality. future teacher.

The purpose of the study is to provide a theoretical analysis and empirical study of the creative potential of

The research has used the following techniques: "Your creative potential" (A.N.Luk), "Diagnosis of personal creative abilities" (YeYe.Tunik).

The study has concluded that students have an average creative potential, they are prone to risk and curiosity, have an average level of motivation to succeed and give recommendations for their development.

The practical significance of the results is that the materials of the research can be used in the work of psychologists and teachers of higher educational establishments in order to create favorable conditions for the training and upbringing of students and the development of their creative abilities, which will promote the successful professional formation of future teachers.

Key words: creativity, teacher's potential, creative activity, creative personality, tea. 